\title{
CURRENT TRENDS IN INCLUSIVE PRIMARY SCHOOL
}

TENDÊNCIAS ATUAIS NA ESCOLA PRIMÁRIA INCLUSIVA

\author{
TENDENCIAS ACTUALES EN LA ESCUELA PRIMARIA INCLUSIVE
}

\author{
Samoilova Iryna ${ }^{1}$ \\ Kozynets V. Oleksandr ${ }^{2}$ \\ Havrylenko Tetiana ${ }^{3}$ \\ Popadych Olena ${ }^{4}$ \\ Bondarenko Yuliia ${ }^{5}$
}

\begin{abstract}
Inclusive education is an important part of the general humanitarian attitude to create equal living conditions and self-realization of various members of society. It is important to diversify approaches to inclusive pedagogy. In particular, the need to take into account age differences in the education of children with disabilities, the need to distinguish inclusive tactics depending on the level of education, the requirement to systematize approaches to inclusive pedagogy from its first structural link and to potentially vocational education. In the system of inclusive education, the primary school occupies a prominent place as the first compulsory educational institution. Aim. The purpose of the article is to consider and analyze current trends in inclusive education in primary school. Methods and instruments. The main research methods are the analysis of the regulatory framework (international policy documents), processing of statistical data, study and generalization of recent publications on the topic with an emphasis on the experience of the leading European countries. Results and conclusion. It is established that the main trends in the development of inclusion at the primary school level are: a) shifting away from specialized schools and classes in favor of increasing inclusive classes; b) finding ways to overcome the inequality of funding for inclusive education in European countries and the inequality of the allocation of the budget that is allocated to the financing of inclusive education ( primary schools); c) active support of inclusive education by the world community, development of basic international documents and programs in order to standardize theoretical, practical and technical approaches to inclusion in primary school; d) finding opportunities to engage in inclusive practices for skilled people with disabilities; e) search for methods of overcoming social and psychological barriers to inclusive education of primary school children; f) a structured approach to inclusive education in
\end{abstract}

\footnotetext{
${ }^{1}$ Kharkiv Humanitarian Pedagogical Academy. Kharkiv, Ukraine.

${ }^{2}$ National Pedagogical Dragomanov University. Kiev, Ukrraine.

${ }^{3}$ T. H. Shevchenko National University «Chernihiv Colehium». Chernihiv, Ukaine.

${ }^{4}$ Uzhhorod National University. Uzhhorod, Ukraine.

${ }^{5}$ Sumy State Pedagogical University. Sumy, Ukraine.
} 
primary school; g) development of a single mechanism for initiating inclusive education and monitoring the implementation of the recommendation on inclusive education, determining its effectiveness.Perspectives. Further attention to the trends of inclusive education is quite relevant. We have to understand the current and future vectors of inclusive education in the world. Nowadays, inclusive education becomes a trend and a prerequisite for ensuring the principle of parity in the humanities, ensuring equal conditions for human development.

Keywords: Inclusive education, inclusive education trends, primary school, children with disabilities, children with special needs, special educational needs, primary school student.

Resumo: A educação inclusiva é uma parte importante da atitude humanitária geral para criar condições de vida iguais e auto-realização de vários membros da sociedade. É importante diversificar as abordagens da pedagogia inclusiva. Em particular, a necessidade de levar em consideração as diferenças de idade na educação de crianças com deficiência, a necessidade de distinguir táticas inclusivas dependendo do nível de educação, a necessidade de sistematizar abordagens para a pedagogia inclusiva desde seu primeiro elo estrutural e para a educação potencialmente vocacional . No sistema de educação inclusiva, a escola primária ocupa lugar de destaque como primeira instituição educacional obrigatória. Alvo. O objetivo do artigo é considerar e analisar as tendências atuais da educação inclusiva na escola primária. Métodos e instrumentos. Os principais métodos de investigação são a análise do quadro regulamentar (documentos de política internacional), tratamento de dados estatísticos, estudo e generalização de publicações recentes sobre o tema com ênfase na experiência dos principais países europeus. Resultados e conclusão. Constata-se que as principais tendências no desenvolvimento da inclusão no nível da escola primária são: a) o afastamento das escolas e classes especializadas em favor do aumento das classes inclusivas; b) encontrar formas de ultrapassar a desigualdade de financiamento da educação inclusiva nos países europeus e a desigualdade na atribuição do orçamento que é atribuído ao financiamento da educação inclusiva (escolas primárias); c) apoio ativo à educação inclusiva pela comunidade mundial, desenvolvimento de documentos e programas internacionais básicos a fim de padronizar abordagens teóricas, práticas e técnicas para a inclusão na escola primária; d) encontrar oportunidades para se envolver em práticas inclusivas para pessoas qualificadas com deficiência; e) busca de métodos de superação de barreiras sociais e psicológicas à educação inclusiva de crianças do ensino fundamental; f) uma abordagem estruturada da educação inclusiva na escola primária; g) desenvolvimento de um mecanismo único para iniciar a educação inclusiva e monitorar a implementação da recomendação sobre educação inclusiva, determinando sua eficácia. Perspectivas. Mais atenção às tendências da educação inclusiva é bastante relevante. Precisamos compreender os vetores atuais e futuros da educação inclusiva no mundo. Hoje, a educação inclusiva torna-se uma tendência e um pré-requisito para assegurar o princípio da paridade nas humanidades, garantindo condições iguais para o desenvolvimento humano.

Palabras clave: Educação inclusiva, tendências da educação inclusiva, escola primária, crianças com deficiência, crianças com necessidades especiais, necessidades educacionais especiais, aluno da escola primária.

Resumen: La educación inclusiva es una parte importante de la actitud humanitaria general para crear condiciones de vida iguales y la autorrealización de varios miembros de la sociedad. Es importante diversificar los enfoques de la pedagogía inclusiva. En particular, la necesidad de tener en cuenta las diferencias de edad en la educación de los niños con discapacidad, la necesidad de distinguir las tácticas inclusivas en función del nivel educativo, la exigencia de sistematizar los enfoques de la pedagogía inclusiva desde su primer vínculo estructural y la educación potencialmente profesional. . En el sistema de educación inclusiva, la escuela primaria ocupa un lugar destacado como primera institución educativa obligatoria. Objetivo. El propósito del artículo es considerar y analizar las tendencias actuales en educación inclusiva en la escuela primaria. Métodos e instrumentos. Los principales métodos de investigación son el análisis del marco regulatorio (documentos de política internacional), procesamiento de datos estadísticos, estudio y generalización de 
publicaciones recientes sobre el tema con énfasis en la experiencia de los principales países europeos. Resultados y conclusión. Se establece que las principales tendencias en el desarrollo de la inclusión a nivel de la escuela primaria son: a) alejamiento de las escuelas y clases especializadas a favor de incrementar las clases inclusivas; b) encontrar formas de superar la desigualdad en la financiación de la educación inclusiva en los países europeos y la desigualdad en la asignación del presupuesto que se asigna a la financiación de la educación inclusiva (escuelas primarias); c) el apoyo activo de la educación inclusiva por parte de la comunidad mundial, el desarrollo de documentos y programas internacionales básicos para estandarizar los enfoques teóricos, prácticos y técnicos de la inclusión en la escuela primaria; d) encontrar oportunidades para participar en prácticas inclusivas para personas capacitadas con discapacidades; e) buscar métodos para superar las barreras sociales y psicológicas a la educación inclusiva de los niños de la escuela primaria; f) un enfoque estructurado de la educación inclusiva en la escuela primaria; g) desarrollo de un mecanismo único para iniciar la educación inclusiva y monitorear la implementación de la recomendación sobre educación inclusiva, determinando su efectividad. Es muy importante prestar más atención a las tendencias de la educación inclusiva. Tenemos que comprender los vectores actuales y futuros de la educación inclusiva en el mundo. Hoy en día, la educación inclusiva se convierte en una tendencia y un requisito previo para asegurar el principio de paridad en las humanidades, asegurando la igualdad de condiciones para el desarrollo humano.

Palavras-chave: Educación inclusiva, tendencias de educación inclusiva, escuela primaria, niños con discapacidad, niños con necesidades especiales, necesidades educativas especiales, estudiante de primaria.

\section{INTRODUCTION}

Inclusive education corresponds to the global trend. It creates equal and quite comfortable conditions for the education of different categories of students, in particular students with special needs. This is the main point, the basic concept in the formation of trends in modern pedagogical approaches. It helps to create an educational environment that is equally comfortable for different categories of students. Moden inclusive practice shows significant progress in increasing the number of inclusive classes, which contributes to the socialization of students with special needs, conscious attitude of students without special educational needs to those who have medical diagnosis of abnormalities in physical or mental development. Such children have recommendations from social services on the necessity to attend an inclusive class and the need for inclusive pedagogical practices.

All this increases the experience of mankind in terms of effective interaction with such students, humane treatment towards children with special needs, their involvement in traditional forms of social life in positions of active participation, rather than passive observer. Inclusive education is based on the position that most students with special needs can and should study in regular education classes. And only a small minority with significant physical or mental disabilities may potentially need a separate specialized environment (such as a special class or specialized school). The basic principles of inclusive education are regulated by official documents that are ratified at the level of international organizations. UN policy is fundamental to the implementation of the principles of inclusion. Issues of inclusive education of children from birth to adulthood are delegated to UNICEF.

In addition, the UN has a special Department of Economic and Social Affairs Disability, which regulates general issues of socialization of people with disabilities. The UN Convention on the Rights of Persons with Disabilities (UNCRPD) was signed in 2003 and entered into force in 2008. As of November 2019, this document was ratified by 180 states and the European Union. The Committee on the Rights of Persons with Disabilities monitors the declared principles of the convention. An annual conference of UNCRPD member states is held, at which the signatory members of the convention agree on current areas of inclusion. The twelfth session of the conference took place in June 2019 in New York. 
Emphasis is placed on the fact that the social integration of people with disabilities is in the context of ensuring fundamental human rights and is one of the most important spheres of UN action. It is also one of the tasks set out in the program "Transforming our world". The 2030 Agenda for Sustainable Development was adopted in 2015. People with disabilities are a matter of justice as well as a reasonable investment in the common well-beingof mankind. In 2018, The United Nations Disability Inclusion Strategy was adopted.

In addition, the International Association of Special Education (USA), that was founded in 1985, plays a significant role in implementing the principles of inclusion at all levels of society. The organization includes specialists from 50 countries, including teachers, professors, etc., who deal with issues of inclusive pedagogy.

Inclusive pedagogy is based on the belief that absolutely all students are full members of the educational community. Assessing the current trends of inclusive education, we should understand the bilateralism of this concept: on the one hand, these are modern directions in the methodology of organizing the educational process, but the first thing that precedes and without which it is impossible to implement a successful inclusive project is the training of teachers. They have to know the practices of inclusive school education.

In addition, the key to the success of a student with special needs in elementary school and in the following stages is the formed and conscious attitude of parents / guardians about the need for inclusion, its importance for children with special needs, understanding all the benefits of socialization of a disabled kid. This is often hindered by a serious psychological barrier. It is about the unwillingness to show problems that are associated with the physical or mental development of a potential student, the threat of bullying and so on.

The primary school is institutionally the second stage in the structure of education. It is preceded by inclusive practices applied at the preschool (nursery) level, in relation to which the primary school should ideally implement the principle of system and continuity. However, pre-school education is not compulsory in all countries of the world, so primary school is often designed to start a complex process of inclusive education to meet the educational needs of children with disabilities.

A review of the current literature on inclusive education points us to the conclusion that despite the significant amount of research in the field of inclusive pedagogy, the availability of cases that allow to draw correct conclusions. There is a necessity to develolp the practices of inclusive education in specific countries or according to specific learning conditions. There is the need for research inclusive education. This persists even with a time perspective. Sush study requires a comprehensive approach to understanding the basics of this concept and not only because inclusion is a trend that is on the verge of pedagogy, psychology and sociology. First of all, inclusive education corresponds to the basic foundations of humanism. Humanism through inclusion becomes more substantive in today's environment of human society.

The analysis of scientific publications on the topic also raises the urgent need to diversify approaches to inclusive pedagogy. In particular, it requires the formation of clear approaches, methods to inclusive education at different stages of education: from preschool to the inclusion in higher education. There is very little research that would thoroughly analyze current approaches to inclusive education in primary school. Available publications address this topic either very briefly or at the level of case studies with an obvious lack of systematic generalizations based on the results. All this formulates the relevance of this study, which aims to assess current global trends in inclusive education not in general, but with the maximum focus on the environment of primary school. 


\section{LITERATURE REVIEW}

In recent decades the introduction of inclusive education has been the most significant reform in terms of ensuring the principles of humanism, democracy, equality and the largest geographically (Amor et al., 2019; Lakkala, 2019). Today, there is a steady trend to increase the number of students with special needs in inclusive classes and reduce the number of such students in specialized classes, where only children with physical or mental disabilities study (Rafiq, 2019).

There are significant differences in the way of implementation of inclusion among the countries of the world. In addition, on the way to inclusion, countries face unequal challenges, depending on a variety of socio-cultural and economic factors, which prevent them from being addressed systematically and equally in order to level the situation with inclusive education, at least on a continent, if not global.

In particular, Schwab (2020) points out that even the decision on whether a child with special needs will attend an inclusive school or a specialized class is made by different interested parties in different countries. Resources for the implementation of inclusive education also differ significantly (Schwab, 2020).

Among the publications related to the trends of inclusive education in primary school, of particular interest are those that analyze the practical innovative experience on this issue. Such experience is gained through the implementation of innovative principles of inclusive education in certain countries. Gubbels et al. (2018) focuses on the experience of the Netherlands, where the new principles of inclusive education ratified in 2014. The new principles were ratified in the Education Act for Students with Special Needs.

The fundamental position of the act is to make every effort to involve people in the implementation of inclusive education, as well as directly in the upbringing of children with disabilities in order to ensure that the education of students with special needs is conducted in secondary schools. The law provides the responsibility of schools to attract such special students, applying mechanisms of incentives and sanctions to the school administration to prevent abuse, reduce the level of denial of the right of children with disabilities to attend regular school.

The cooperation of schools with specialists from inclusion centers on a partnership basis plays a special role. So, partnerships have been concluded at the regional level in the Netherlands to improve the exchange of resources and knowledge and to stimulate cooperation between schools and organizations for the protection of the rights of people with disabilities in the Netherlands. Egelund \& Dyssegaard (2019), researching inclusive education in Denmark, notice the practice of a bilateral initiative in its implementation: both at the level of parliament and at the level of local governments. And not all municipalities were ready to create economic incentives for inclusion. However, 12 municipalities took part in the Danish experiment. It has showed that the level of inclusion in schools reached $96 \%$ in a short period of time.

Inclusive education is hampered by the inexperience of school teaching staff (Round et al., 2016; Majoko, 2019), and sometimes by an open reluctance to work with students with special educational needs (Subban \& Sharma, 2006). An experimental study by Saloviita (2020) has found that primary school teachers were much more positive about inclusion than secondary school teachers. However, even the absolute perception of inclusive education and the psychological readiness to work with children with disabilities require reinforcement by special teacher training programs and professional development programs.

Paseka \& Schwab (2020) studied the attitude of parents of primary school children with special needs to inclusive education, as well as the problem of perception of inclusive pedagogical practice and resources of inclusion by parents. This perspective is very important, because inclusion is first and foremost an effective model of cooperation between all parts of the process and without parental support it is just impossible to talk about the success of applied practices. The results showed that the attitude of parents to the inclusion of students with physical disabilities or learning disabilities was quite positive, while the inclusion of students with behavioral disabilities or mental disabilities was mostly neutral. 
Another vector of the problem is the attitude of parents of healthy children to the fact that their children study in an inclusive classroom (with at least one student with special educational needs). After all, the hostile attitude of a big number of parents can provoke unwanted conflicts between all participants of the process.

So, according to a study by Paseka \& Schwab (2020), parents of healthy children are mostly positive about most inclusive practices compared to parents whose children attend a regular class (which does not include any students with special educational needs). In addition, the positive or very negative attitude of parents towards inclusive education in general also depends on the specific type of disability.

Magnússon (2020) looks critically at the Swedish education system. It is often recognized as inclusive in the international context, but in practice it often demonstrates the lack of a sufficient level of inclusive tactics. In particular, there is a problem of creating communities for the of schools profiling in the market of educational services.

The range of issues related to inclusive education in general and inclusive education in primary school proves the relevance of the topic, its diversity and complexity. It requires close attention of governments, scientists, parents, teachers to the concept of inclusive education in order to increase its accessibility and effectiveness.

\section{METHODS}

In order to analyze the current state of inclusive education in world practice and identify current trends in inclusive education in primary school, such research methods were used: analysis of policy documents, programs of international organizations in the field of inclusive education (UNICEF, UNESCO, EASIE, EASNIE, Schola Europaea, etc.); elaboration of relevant scientific literature on the topic (scientific articles covering theoretical positions and practical approaches to inclusive education in general and inclusive education in primary school. All articles for the last five years were taken into account); study of demonstrative cases, processing of statistical data obtained as a result of experimental introduction of inclusion practices in different countries of the world with an emphasis on the Western European region; system and logical analysis, method of synthesis and generalization of the received information.

\section{RESULTS}

In this part of our work we propose to consider the main world and European trends in the development of inclusive education in primary school. Trend 3: active support of inclusive education by the world community, development of basic documents that could unify approaches to inclusive education, develop a common standard of inclusion in theoretical and practical terms for primary school.

The basic principles of inclusive education are regulated by official documents ratified at the level of international organizations. They set the pace and direction of innovation in the field of inclusive education. It should be noted that the unifying force for all current documents that regulate inclusion in schools is the tendency to expand inclusive classes.

The European Agency Statistics on Inclusive Education (EASIE) deals with the collection, systematization and synthesis of data on inclusive education at the European level. One of the main tasks of the agency is to prepare a regular report on the dynamics of the implementation of inclusive education. The last one was prepared in 2018. It covers statistics for 2016 on the basis of data from 30 European countries.

The transformation of approaches to inclusive education has been going on since the second half of the 20th century. The UNESCO "Learning to be" program was adopted in 1972. "The world of education today and tomorrow" gave impetus to inclusion (UNESCO, 1972). The active phase of the implementation of 
inclusive education in the world begins with the UNESCO program "The Salamanca Statement and Framework for Action on Special Needs Education", which was ratified in 1994.

The way of representing the results of the agency's work demonstrates a shift from the emphasis on students who have official diagnosis of health workers on special educational needs with their separation into special groups of respondents, to focusing on the total number of students in secondary schools and the number of students enrolled in inclusive classes. This clearly demonstrates the transformation of approaches to inclusion, speaks of the priority of inclusive education and the simultaneous moving away from the stereotype that children with special needs should study exclusively in specially designated educational institutions or at least classes, ie isolated from a healthy part of society.

As of 2016 , an average of $98,19 \%$ of all students with special needs were enrolled in general education classes in 28 respondent countries. The rest (1.81\%) study in separate classes of secondary schools, completely separate special schools, receive non-formal education provided by medical or social services. In addition, a small number of them do not receive school education at all. 17 main goals of sustainable development have been identified. The fourth of them is called "Quality Education". Its content is formulated as the provision of inclusive education and equal quality educational services and lifelong learning opportunities for all.

It is important that the declarative minimum inclusion threshold for European countries is as high as $80 \%$, but the actual figure is much higher: from $92.02 \%$ in Belgium to a record $99.97 \%$ in Italy (EASIE, 2018). Now let's talk about 9-year-old students with special needs, who have primary school education in most countries (according to the International Standard Classification of Education (ISCED). 98.67\% of such students study in the inclusive classes according to the indicators of 22 European countries. The lowest level of inclusive education for 9-year-olds is again shown by Belgium - $93.79 \%$, while the leader is Italy - $99.98 \%$.

The European Agency for Special Needs and Inclusive Education is a key player in Europe in developing trends and regulating inclusive education in general. The Agency provides the necessary support to the Ministries of Education of more than 30 Member States in improving inclusive education policies and practices, as well as working with transnational organizations and involving educators, experts, students and families with children with disabilities to work on adequate advancing policies. They guarantee quality educational opportunities for all categories of students.

Now let's talk about the prospects for inclusive education. The principled position of the European community on this issue is enshrined in Project Europe 2030. The program states that efforts to move towards a low-carbon economy has to keep pace with measures to strengthen social inclusion, especially in education (Project Europe 2030, 2010). The project on inclusive education correlates with the abovementioned Sustainable Development Goals (SDG).

The aim of this study is to characterize current trends in inclusive education in primary school. The percentage of primary school students (5-12 years) with special needs (UNESCO Institute for Statistics, 2012) in relation to the total number of primary school students is important. This distribution in different countries is shown in Figure 1. 


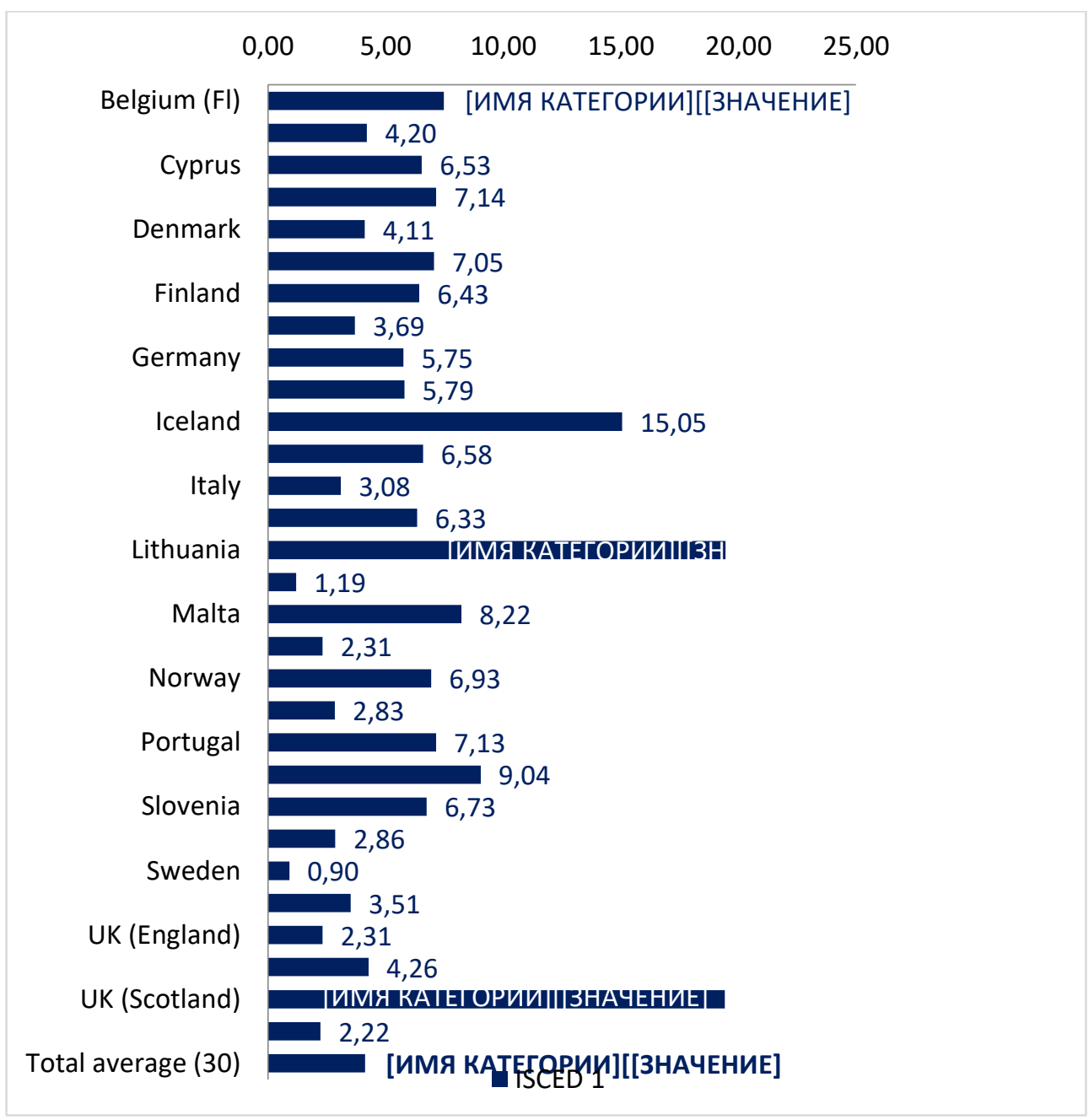

Figure 1. Distribution of pupils with an official decision of special educational needs, based on overall enrolled school population within ISCED 1 (age of entry - not below 5 years old nor above 7 years old; usually lasts until age 10

$$
\text { to } 12)(\%)
$$

Source: The data of European Agency for Special Needs and Inclusive Education (2018)

Figure 1 shows that most children of primary school age who potentially apply for special educational needs are in Scotland (19.42\%) and Lithuania (19.45\%). This is actually one in five children between the ages of 5 and 12 . The most positive dynamics is observed in Sweden (only $0.90 \%$ ) and Luxembourg (1.19\%), where the percentage of "special children" who need inclusive approaches to learning is quite low.

It is further important to analyze how the ratio of all primary school students with special educational needs to those who are recommended to study in inclusive primary schools in Europe has been established (Figure 2). 


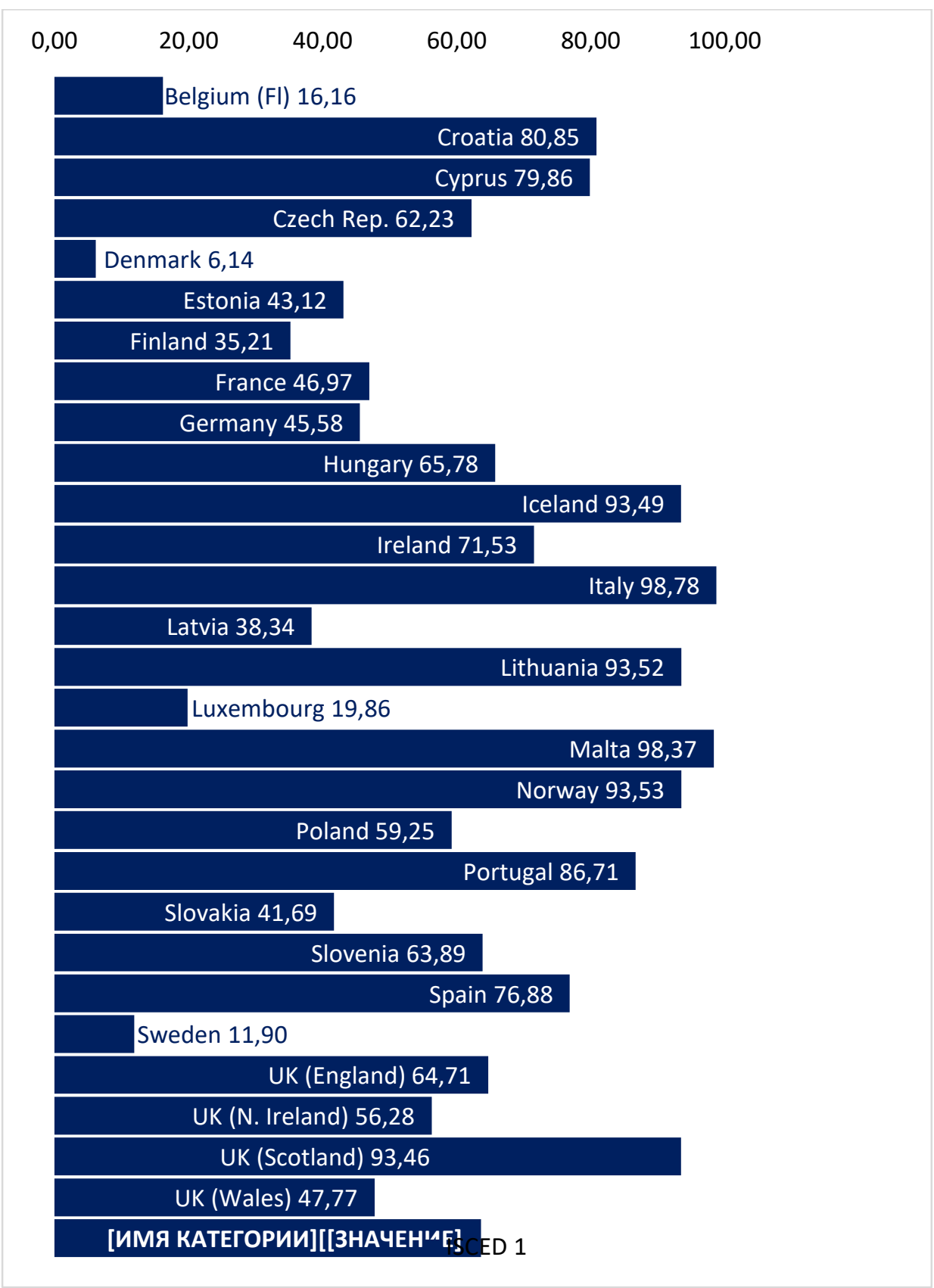

Figure 2. Distribution of pupils with an official decision of special educational needs in inclusive education, based on the population of pupils with an official decision of special educational needs (\%)

Source: The data of European Agency for Special Needs and Inclusive Education (2018)

So, the largest percentage of primary school students (5-12 years) to be involved in inclusive education, relative to the total number of students with special educational needs has Italy $(98.78 \%)$ and Malta (98.37\%), and the lowest percentage has Denmark - only 6.14\%. In total, European countries (28 countries) show a need for inclusive education among the total number of children with special needs at a level slightly above average $-63.62 \%$.

Trend 2: Finding ways to overcome the inequality of inclusive education funding in European countries and the inequality of the budget allocation for inclusive education funding.

An important area of development of approaches to inclusive education is the study of funding for inclusion. However, today the world's leading organizations, which, in fact, promote inclusive education, talk 
about the lack of research on the cost of education in the direction of supporting inclusion. So, the European Agency for Special Needs and Inclusive Education in its 2016 report Financing of Inclusive Education: Background Information Report states that investing in inclusive education is clearly beneficial to society in social, economic and political aspects.

However, the 2016 report presents only general trends in funding without the necessary statistics from European countries. It is stipulated that inclusive education is less expensive than special education for children with special educational needs (specialized boarding schools). However, the agency's representatives speak only about the difficulties in collecting data on the financing of inclusive education in general and the prospects for further statistical generalizations on this issue (European Agency for Special Needs and Inclusive Education, 2016).

Still, such statistics are collected and published. Eurostat data on the cost of primary education in Europe can be used to demonstrate the inequality of funding for inclusive education in primary schools in European countries (Table 1). The table shows that the difference in funding is very significant. It cannot be explained only by the different number of students enrolled in primary schools in these countries. Uneven funding for primary education in general may indicate a significant difference in the share of spending on inclusive education in this total.

Table 1. Primary school educational expenditure of European countries in 2017

\begin{tabular}{|l|l|l|}
\hline No & Country of Europe & Expediture Volume (million euro) \\
\hline 1 & Austria & 3485,5 \\
\hline 2 & Belgium & 7192,6 \\
\hline 3 & Cyprus & 437,6 \\
\hline 4 & Czechia & 1644,3 \\
\hline 5 & Finland & 3044,6 \\
\hline 6 & Germany (until 1990 former territory of the FRG) & 22039,3 \\
\hline 7 & Greece & 2604,5 \\
\hline 8 & Ireland & 3757,4 \\
\hline 9 & Italy & 17903,8 \\
\hline 10 & Latvia & 388,3 \\
\hline 11 & Lithuania & 329,2 \\
\hline 12 & Luxembourg & 634,7 \\
\hline 13 & Malta & 141 \\
\hline 14 & Netherlands & 8599,1 \\
\hline 15 & Norway & 6570,4 \\
\hline 16 & Poland & 7614,8 \\
\hline 17 & Portugal & 3262,6 \\
\hline 18 & Romania & 719,7 \\
\hline
\end{tabular}




\begin{tabular}{|l|l|l|}
\hline 19 & Slovakia & 830,4 \\
\hline 20 & Spain & 16962,5 \\
\hline 21 & Sweden & 9078,5 \\
\hline 22 & Turkey & 7167 \\
\hline $\begin{array}{l}\text { Note: } \text { Countries with no data presented to Eurostat on the criterion of primary education funding } \\
\text { are omitted. }\end{array}$
\end{tabular}

Source: Compiled by the author based on data of Eurostat (2020).

This once again indicates the relevance of research concerning inclusive education in general and inclusion in primary school in particular (this phase is fundamental for all subsequent stages of inclusive school education, because basic learning skills are formed at this stage ). In addition, the countries show a striking dissonance: the percentage of primary school children in need of inclusive education in relation to the total number of children with special needs in Denmark is 16(!) times less than in Italy.

Trend 4: Expanding opportunities to involve qualified people with disabilities in inclusive practice as teachers and mediators in communication with students with speech, vision and hearing impairments.

The standard of living in Denmark is very high. According to the welfare map presented by Marian (2016), the level of well-being in Denmark, calculated on the basis of comprehensive indicators, which also assessed the quality of educational services and access to education, was $91.3 \%$. The country ranks the 8th among the richest countries in Europe (List of sovereign states in Europe by GDP (PPP) per capita, 2020).

Trend 5: Finding ways to overcome social and psychological barriers to expanding inclusive primary school education.

While the indicators for Italy are $70.6 \%$ and the 18th place in the European ranking of the richest countries. So, not all countries can potentially ensure a high level of inclusive education development. This involves significant financial costs, due to the mismatch between the demands for inclusive education and the economic and social capabilities of the country to meet these demands.

Special Inclusive Education Booklets and Webinars have been developed by UNICEF on theoretical and practical issues of inclusive education that are relevant to most countries of the world. Today there are 14 of them and each of these technical booklets is dedicated to a specific area of work on the implementation of inclusion (Figure 3). 


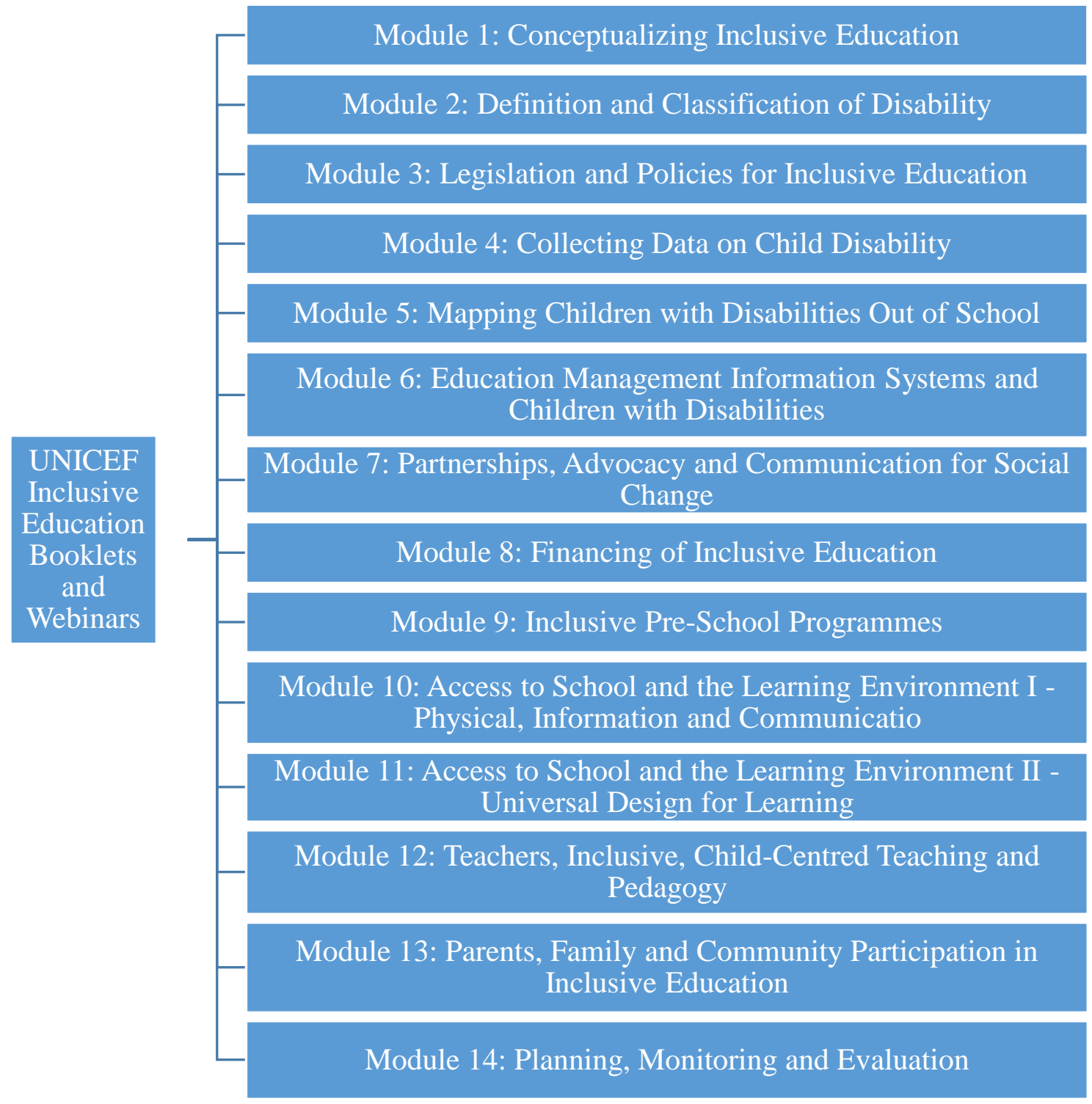

Figure 3. UNICEF Technical Booklets on Inclusive Education

Source: Compiled by the authors based in the data of UNICEF

In the current study, the most interesting are the booklets of modules 1, 3, 6, 10-12. Article 28 of the Convention on the Rights of the Child recognizes the right of all children to receive education. It is the basis for further equal opportunities for self-realization. According to the Convention, primary education should be compulsory and free for every child of the appropriate age.

It is the primary level of education that is considered to be the starting point in reforming the entire mechanism of modern pedagogy in accordance with the principles of inclusion (UNICEF, 2017). However, according to UNICEF, children with disabilities are very often literally excluded from the education system, starting from the primary school level (UNICEF, 2016b). It is the primary level of the secondary school system that has the main responsibility for the maximum involvement of children with special educational needs in inclusive classes.

This issue is clearly regulated in Article 24 of the Convention on the Rights of Persons with Disabilities, which states that persons with disabilities should be guaranteed the right to access inclusive, quality and free primary and secondary education on an equal basis with others in the communities in which they live. This 
includes both the theoretical and methodological side of the issue and the logistical support of schools with various devices for the needs of children with disabilities (according to the classifier of disability).

In particular, this may require specially equipped driveways, corridors, dining rooms, toilets, desks, the availability of textbooks and manuals in Braille or other alternative ones, the need to teach in sign language and so on in the organization of environment of an inclusive primary school.

Public authorities should promote employment in schools that participate in inclusion programs, teachers with disabilities who are fluent in sign language and / or Braille in order to realize the rights of children with disabilities. This will aim not only to implement the direct responsibilities of teaching, but also help to teach the administrative and teaching community the basics of interaction with students with special educational needs.

In addition, such employment of people with special needs will be the culmination of the whole complex process of inclusion. The ultimate goal of such process is to blur the line between healthy people and people with disabilities. The realization of an individual with special professional needs is the best evidence of full socialization and the success of inclusive approaches. Primary school teachers can and should become mediums for inclusive teaching and socialization tactics for children with disabilities (UNICEF, 2016a). At the same time, the problem of lack of specially trained staff for adequate implementation of the practice of inclusion is very acute. It has already been partially discussed above (UNICEF, 2016).

As of 2015 , as many as $9 \%$ (58 million) of primary school students worldwide are deprived of the opportunity to receive education (Fixing the broken promise of education for all, 2015). The official reports of international organizations on inclusion show that various barriers stand in the way of the inclusion of a child with a disability in general education. This is a bigger problem than disability itself (Fixing the broken promise of education for all, 2015). Other factors can also be obstacles. In particular, a big problem is a typical combination of disability with family poverty or unhappiness, which together hinders the necessity to educate a child with a disability. According to the World Disability Report $2011,80 \%$ of people with disabilities live in developing countries and people with special needs come from low-income families (Fixing the broken promise of education for all, 2015).

The current trend of inclusive education in primary school is also the need for the correct distribution of funds that is allocated to support inclusive education. In 2018, the EU initiated the development of a Report on "Inclusive Education in the European Schools" (Schola Europaea, 2018). There are three levels of education support in the EU: General Support, Moderate Support, Intensive B Support (ISB) and Intensive A Support (ISA). We are interested in the latest type of assistance. ISA is provided after an expert assessment of a student's special individual needs and the signing of an agreement between the school and parents and is implemented to support students with special educational needs: learning, emotional, behavioral or physical needs. The use of the ISA budget can be demonstrated by the example of reporting data from European countries for 2016-2017 (Table 1). Most of the budget (about 74\%) is used to pay teachers. The percentage of the budget used to pay the salaries of assistants is about $23 \%$. Table 1 allows you to compare the use of ISA funds also depending on the degree of the school. It is noticeable that the financing of inclusive education at the stage of preschool education is quite trivial (preschool inclusion as one of the current trends will be discussed below). Teachers' salaries in primary school are spent $14.6 \%$ less than in secondary school. It is a significant difference. It can be objectively explained by the number of involved teachers, which is higher in secondary school. On the other hand, the funds allocated for the salaries of assistants in primary school are three times higher than in secondary school, which is also explained by the need to increase the assistance of an early school child in acquiring social and self-care skills during school. As the table shows, the costs of special educational equipment for students with special needs are absolutely low at all levels. The budget used for teaching materials, including ICT for educational support, is only about $1 \%$. 
The situation was similar in the academic years 2014-2015 and 2015-2016. Other expenses, apart from the indicated basic financing needs, are completely invisible within the framework of the report. All this is a consequence of the imperfection of the practice of using the budget for inclusive education. First, lack of funding (although its volume is constantly growing), and secondly, illiteracy in distribution.

Table 1. Use of the ISA budget by cycle in the year 2016-2017 by European Primary Schools

\begin{tabular}{|l|l|l|l|l|}
\hline Average of all schools & Nursery & Primary & Secondary & $\mathrm{N}+\mathrm{P}+\mathrm{S}$ \\
\hline ISA teaching & $1,4 \%$ & $29,7 \%$ & $44,3 \%$ & $75,4 \%$ \\
\hline ISA assistance & $3,8 \%$ & $14,2 \%$ & $5,5 \%$ & $23,5 \%$ \\
\hline $\begin{array}{l}\text { Pedagogical material and } \\
\text { equipment for ISA (including } \\
\text { ICT) }\end{array}$ & $0,0 \%$ & $0,5 \%$ & $0,4 \%$ & $0,9 \%$ \\
\hline Other & $0,0 \%$ & $0,0 \%$ & $0,0 \%$ & $0,0 \%$ \\
\hline TOTAL & $5,3 \%$ & $44,3 \%$ & $50,3 \%$ & $99,9 \%$ \\
\hline
\end{tabular}

Source: Schola Europaea (2018)

Trend 1: Maximum abandonment of specialized schools and classes in favor of increasing inclusive classes in primary school.

Another factor that is detrimental to the effectiveness of inclusion in primary school is that children with disabilities have very limited participation in preschool inclusive education programs. So, compared to children without special needs, who usually attend preschool and receive basic socialization skills, children with disabilities, in addition to learning the material, in primary school have a priority to develop team-skills. If a child with a disability does not attend an inclusive preschool, it reduces his or her ability to gain the necessary social experience and skills to help him or her adapt to the school environment when entering school.

Trend 4: Expanding opportunities to involve qualified people with disabilities in inclusive practice as teachers and mediators in communication with students with speech, vision and hearing impairments.

Trend 5: Finding ways to overcome social and psychological barriers to expanding inclusive primary school education.

Trend 6: Structural-level approach to inclusive education in primary school, which means the continuity of the stage of primary education in the paradigm of inclusion in relation to inclusive practices of preschool education.

European inclusive education practice usually stipulates that the responsibility for providing appropriate educational services to children with special needs lies with the relevant local government departments. It is their responsibility to ensure that the maximum percentage of children with special educational needs are enrolled in primary school (a system of inclusive pre-school education also exists, but is not currently mandatory)

So, the European Agency for Special Needs and Inclusive Education initiated a three-year project (2015-2017) Inclusive Early Childhood Education as part of the general project Quality Framework for Early Childhood Education and Care, which has been implemented since 2014. The IECE project addresses the 
needs of social adaptation and education of children with special needs from the age of 3 to the beginning of primary education, which usually lasts 5-7 years. The IECE project involved countries such as Austria, Belgium, Croatia, Cyprus, the Czech Republic, Denmark, Estonia, Finland, France, Germany, Greece, Hungary, Iceland, Ireland, Italy, Latvia, Lithuania, Luxembourg, Malta, the Netherlands and Norway, Poland, Portugal, Slovakia, Slovenia, Spain, Sweden, Switzerland and the United Kingdom. Two experts from each of these countries were involved in the project activities. The results of the project were summarized in the Inclusive Early Childhood Education report. New Insights and Tools Final Summary Report (2017) is a very important stage in the promotion of early inclusive education with an emphasis on the systematic continuation of its foundations in primary school. One of the most notable achievements is the development of a special The Ecosystem Model of Inclusive Early Childhood Education. It provides a clear understanding of approaches to the organization and implementation of inclusive education in early childhood and the importance of this stage for further learning and socialization of people with special needs.

Competent international organizations such as The Inclusive Schools Network (ISN), the National Association for the Education of Young Children (NAEYC), AbilityPath and others are also working to promote and develop the theoretical and practical foundations for the introduction of preschool inclusive education.

Trend 7: development of a single mechanism for initiating inclusive education and monitoring the implementation of the recommendation on inclusive education, determining the effectiveness of inclusive practices.

At European Union (EU) level, Article 26 of the Charter of Fundamental Rights of the European Union, adopted in 2000, sets out a guiding principle for EU legislative and policy measures to support the full inclusion of children with disabilities. In addition, the EU is committed to support the removal of legal and organizational barriers for people with disabilities through the Education and Training 2020 program. This requires the development of clear mechanisms for regulating this issue in the Organization of Provision to Support Inclusive Education - Summary Report (European Agency for Special Needs and Inclusive Education, 2014).

The official document of UNESCO Inclusive education and accountability mechanisms (UNESCO, 2017) is further devoted to the problems of regulation of mechanisms of inclusive education from primary school.

The initiators of the initial request for inclusive education are usually parents, who have the right to apply to educational and psychological counseling services at local authorities in order to organize special educational assistance to a child of primary school age. However, the initiators can also be teachers (if the child demonstrates the need for special educational approaches in the process of learning) or doctors who have a child with potential needs for inclusion.

Parents have to agree to any special educational assistance. If parents do not agree with the decisions of the special commissions, they can file a complaint to the Board of Appeal for Inclusive Education. Every year a detailed report is submitted with a reassessment of the physiopsychological condition of a disabled child. A conclusion is formed about the success of the impact of inclusive education on its basis.

\section{DISCUSSION}

It is important to understand that the interests of a student with special educational needs should be at the forefront in the introduction of any innovative methods. It is necessary for a substantive understanding of the development of inclusive teaching practices. And the starting point should be that when we talk about children with special needs, we do not mean passive, unconscious objects of educational services, but active and the main participants in the process who initiate inclusion. They have the 
fundamental right to determine own vectors of transformations towards personal goals (Snipstad, 2020; Barevičiūtè et al., 2019; Bunbury, 2020).

Inclusive education, like regular education, has every chance to take place on the basis of "subject-subject" relations between its participants. The role of the child with special needs in making the inclusive environment as comfortable and productive as possible is growing with this awareness. To treat students as the main catalysts for qualitative transformations of inclusive education is in the mainstream of the world's best practices of inclusion (Messiou, 2019). It is also so even when it is about primary school students.

Various interactive practices, questionnaires, conversations, reflections of students with special needs on the conditions of the educational environment in which they are, should become a constant form of feedback. These methods will choose most effectively promising areas of inclusive pedagogy (WilliamsBrown \& Hodkinson, 2020).

It is also important to involve people who have participated in inclusive education. They might be very importnt in the work of introducing inclusion in secondary school. The President of People First of Canada, Kory Earle studied in an inclusive classroom. According to him, the methodology of inclusive education, starting from primary school and ending with higher education, helped him to assert himself, become more confident in his own abilities, take an active part in public life and contribute to his inner development of a conscious and fully independent position (CRPD, 2019).

There is always the question of financing the special educational needs of students with disabilities in the implementation of inclusive education. In particular, it is about the proper technical organization of the educational space of primary school, where these needs, compared to other levels of inclusive education programs, are most financially costly. Demographic trends and funding mechanisms for inclusive education primarily affect the number of children with special educational needs in primary school. The inclusion process at all levels also depends on the socio-cultural region in which it is implemented (Page et al., 2020).

A significant disadvantage at the present stage is that the experience of inclusive education in primary and secondary education does not trasform into a successful transition to further stages of education for many students with disabilities. It is especially true in terms of vocational and higher education. We do not even talk about further employment. So, there is an urgent need to develop and implement detailed programs of inclusive pedagogy, which would consolidate and develop the learning skills that are acquired in primary school.

\section{CONCLUSION}

The experience of the European countries are very illustrative for this study. Inclusive education is a prerequisite for achieving a more abstract goal of making society a friendly environment for all its members by reducing discrimination.

Based on the results of the study, the key trends in inclusive education in primary school, which can be identified on the basis of serious and comprehensive analysis of European inclusive practice are: shifting away from specialized schools and classes in favor of increasing inclusive classes in primary school; finding ways to overcome the inequality of funding for inclusive education in European countries and the inequality of the distribution of the budget allocated for the financing of inclusive education, in particular in primary schools; active support of inclusive education by the world community, development of basic documents that would unify approaches to inclusive education, develop a single standard of inclusion of primary school in theoretical, practical and technical terms; expanding opportunities to involve qualified people with disabilities in inclusive practice in the role of teachers and mediators in communication with students with speech, vision and hearing impairments; search for methods of overcoming social and 
psychological barriers on the way to expanding inclusive education of primary school students; structural approach to inclusive education in primary school, which means the continuity of the stage of primary education in the paradigm of inclusion in relation to inclusive practices of preschool education; development of a single mechanism for initiating inclusive education and monitoring the implementation of the recommendation on inclusive education, determining its effectiveness.

The difficulties of introducing inclusive pedagogy are due to the fact that this is an issue that requires not just organizational and technical implementation, but involves a complex process of transformation in culture, philosophy of society. This process places a commitment on each education system in every country in order to socially adapt children with mental or physical disabilities and to meet their educational needs and rights. Further attention to the trends of inclusive education is relevant in understanding the current and future vectors of inclusive education in the world. The comparative direction of research of tendencies of inclusive education in various historical and cultural regions is perspective.

\section{REFERENCES}

Ahmmed, M., Sharma, U., \& Deppeler, J. (2014). Variables affecting teachers' intentions to include students with disabilities in regular primary schools in Bangladesh. Disability \& Society, 29(2), 317331. https://doi.org/10.1080/09687599.2013.796878

Amor, A. M., Hagiwara, M., Shogren, K. A., Thompson, J. R., Verdugo, M. Á., Burke, K. M., \& Aguayo, V. (2019). International perspectives and trends in research on inclusive education: a systematic review. International Journal of Inclusive Education, 23(12), 1277-1295. https://doi.org/10.1080/13603116.2018.1445304

Barevičiūtè, J., Asakavičiūtè, V., Grincevičius, J., \& Grincevičienè, V. (2019). Inclusive education as a value: philosophical and socio-educational approaches. Bulletin of Tomsk State University "Philosophy. Sociology. Political Science", 50, 47-54.

http://vital.lib.tsu.ru/vital/access/services/Download/vtls:000667042/SOURCE1

Boa Sorte, P. (2020). Mark the correct answer? To whom? Deconstructing reading comprehension. Journal of Research and Knowledge Spreading, 1(1), 1-8. https://doi.org/10.20952/irks1111550

Bunbury, S. (2020). Disability in higher education-do reasonable adjustments contribute to an inclusive curriculum? International Journal of Inclusive Education, 24(9), 964-979.

https://doi.org/10.1080/13603116.2018.1503347

CRPD. (2019). Report of the twelfth session of the Conference of States Parties to the Convention on the Rights of Persons with Disabilities. Conference of States Parties to the Convention on the Rights of Persons with Disabilities Twelfth session. New York, 11-13 June 2019.

https://undocs.org/en/CRPD/CSP/2019/5

Dias, A. F., Cardoso, H. de M., Santos, A. L. dos, Menezes, C. A. A., \& Rios, P. P. S. (2017). Schooling and subversions of gender. Revista Tempos e Espaços em Educação, 10(22), 83-92. https://doi.org/10.20952/revtee.v10i22.6433

Egelund, N., \& Dyssegaard, C.B. (2019). Forty Years After Warnock: Special Needs Education and the Inclusion Process in Denmark. Conceptual and Practical Challenges. Front. Educ., 4, 54. https://doi.org/10.3389/feduc.2019.00054

Ebrahimi, M. A. (2020). Cultural value of translation of proverbs and synopsis. Journal of Research and Knowledge Spreading, 1(1), 1-10. https://doi.org/10.20952/jrks1111484 
European Agency for Special Needs and Inclusive Education. (2018). European Agency Statistics on Inclusive Education: 2016 Dataset Cross-Country Report. (J. Ramberg, A. Lénárt, and A. Watkins, eds.). Odense, Denmark.

Fixing the Broken Promise of Education for All. Findings from the Global Initiative on Out-of-School Children. (2015). http://uis.unesco.org/sites/default/files/documents/fixing-broken-promise-efafindings-global-initiative-oosc-education-2015-en 2.pdf

Fullagar, S. (2019). A physical cultural studies perspective on physical (in)activity and health inequalities: the biopolitics of body practices and embodied movement. Revista Tempos e Espaços em Educação, 12(28), 63-76. https://doi.org/10.20952/revtee.v12i28.10161

Gubbels, J., Coppens, K. M., \& de Wolf, I. (2018). Inclusive education in the Netherlands: How funding arrangements and demographic trends relate to dropout and participation rates. International Journal of Inclusive Education, 22(11), 1137-1153. https://doi.org/10.1080/13603116.2017.1416684

Kaysılı, A., Soylu, A., \& Sever, M. (2019). Exploring major roadblocks on inclusive education of Syrian refugees in school settings. Turkish Journal of Education, 8(2), 109-128. https://dx.doi.org/10.19128/turje.496261

Lakkala, S. (2019). Tracing Inclusive Education and Its Prerequisites in the Finnish Education System. In: T.M. Paksuniemi \& P. Keskitalo (Eds.) Introduction to the Finnish Educational System (pp. 15-32). Brill Sense. https://doi.org/10.1163/9789004394278 002

List of sovereign states in Europe by GDP (PPP) per capita. (2020). https://en.wikipedia.org/wiki/List of sovereign states in Europe by GDP (PPP) per capita

Magnússon, G. (2020). Inclusive education and school choice lessons from Sweden. European Journal of Special Needs Education, 35(1), 25-39. https://doi.org/10.1080/08856257.2019.1603601

Majoko, T. (2019). Teacher key competencies for inclusive education: Tapping pragmatic realities of Zimbabwean special needs education teachers. Sage Open, 9(1). https://doi.org/10.1177\%2F2158244018823455

Marian, J. (2016). Best countries to live in Europe, 2016 map. https://jakubmarian.com/best-countries-tolive-in-europe-in-2016/

Messiou, K. (2019). The missing voices: Students as a catalyst for promoting inclusive education. International Journal of Inclusive Education, 23(7-8), 768-781. https://doi.org/10.1080/13603116.2019.1623326

Page, A., Mavropoulou, S., \& Harrington, I. (2020). Culturally responsive inclusive education: The value of the local context. International Journal of Disability, Development and Education, 1-14. https://doi.org/10.1080/1034912X.2020.1757627

Paseka, A., \& Schwab, S. (2020). Parents' attitudes towards inclusive education and their perceptions of inclusive teaching practices and resources. European Journal of Special Needs Education, 35(2), 254-272. https://doi.org/10.1080/08856257.2019.1665232

Rafiq, M.S.F.N. (2019). Quality Improvement through Inclusive Education at Primary School Level. Journal of Research, 13(1), 81-91.

Round, P. N., Subban, P. K., \& Sharma, U. (2016). 'I don't have time to be this busy.'Exploring the concerns of secondary school teachers towards inclusive education. International Journal of Inclusive Education, 20(2), 185-198. https://doi.org/10.1080/13603116.2015.1079271 
Saloviita, T. (2020). Attitudes of teachers towards inclusive education in Finland. Scandinavian Journal of Educational Research, 64(2), 270-282. https://doi.org/10.1080/00313831.2018.1541819

Santos, I. T. R., Barreto, D. A. B., \& Soares, C. V. C. O. (2020). Formative assessment in the classroom: the dialogue between teachers and students. Journal of Research and Knowledge Spreading, 1(1), 114. https://doi.org/10.20952/jrks1111483

Schwab, S. (2020). Inclusive and Special Education in Europe. Oxford Research Encyclopedias. https://doi.org/10.1093/acrefore/9780190264093.013.1230

Snipstad, Ø.I.M. (2020). Inclusive education:'making up'the normal and deviant pupil. Disability \& Society, 35(7), 1124-1144. https://doi.org/10.1080/09687599.2019.1680342

Subban, P., \& Sharma, U. (2006). Primary school teachers' perceptions of icnlusive education in Victoria, Australia. International Journal of Special Education, 21(1), 42-52.

UNESCO Institute for Statistics. (2012). International Standard Classification of Education ISCED 2011. http://uis.unesco.org/sites/default/files/documents/international-standard-classification-ofeducation-isced-2011-en.pdf

UNESCO Office Bangkok and Regional Bureau for Education in Asia and the Pacific. (2009). Towards inclusive education for children with disabilities: a guideline.

https://unesdoc.unesco.org/ark:/48223/pf0000192480

UNICEF. (2014). Legislation and Policies for Inclusive Education, Webinar 3 - Companion Technical Booklet. http://www.inclusiveeducation.org/sites/default/files/uploads/booklets/IE Webinar Booklet 3.pdf

UNICEF. (2016a). Guide for Including Disability in Education Management Information Systems. http://training.unicef.org/disability/emergencies/downloads/UNICEF guide-for-includingdisability-in-education-management-information-systems.pdf

UNICEF. (2016b). Module 6: Education Management Information Systems and Children with Disabilities. http://training.unicef.org/disability/emergencies/downloads/UNICEF guide-for-includingdisability-in-education-management-information-systems.pdf

UNICEF. (2016c). Teachers, Inclusive, Child-Centred Teaching and Pedagogy. Webinar 12 - Companion Technical Booklet. https://www.unicef.org/eca/sites/unicef.org.eca/files/IE Webinar Booklet 12.pdf

UNICEF. (2017). Inclusive Education. Including children with disabilities in quality learning: what needs to be done? https://www.unicef.org/eca/sites/unicef.org.eca/files/IE summary accessible 220917 brief.pdf

Williams-Brown, Z., \& Hodkinson, A. (2020). Development of Inclusive Education in England: Impact on Children with Special Educational Needs and Disabilities. Handbook on Promoting Social Justice in Education, 1561-1583. https://link.springer.com/content/pdf/10.1007/978-3-030-14625- 


\section{ABOUT THE AUTHORS}

\section{Samoilova Iryna}

Candidate of Pedagogical Sciences, Docent Department of Correctional Education and Special Psychology, Municipal establishment «Kharkiv humanitarian pedagogical academy» of Kharkiv regional council. Kharkiv, Kharkiv Oblast, Ukraine.

E-mail: rud prof@ukr.net

ORCID: https://orcid.org/0000-0003-1933-525X

\section{Kozynets V. Oleksandr}

Candidate of Pedagogical Sciences, Faculty of Special and Inclusive Education, Department of Speech Therapy and Speech Psychology, National Pedagogical Dragomanov University. Kiev, Ukrraine.

E-mail: matviichukolexander8@gmail.com

ORCID: https://orcid.org/0000-0002-6325-4783

\section{Havrylenko Tetiana}

Doctor of Pedagogical Sciences, Associate Professor, Psychological and pedagogical faculty, Department of Social Work and Educational and Pedagogical Sciences. T. H. Shevchenko National University "Chernihiv Colehium». Chernihiv, Ukaine.

E-mail: t.a.chajuk@gmail.com

ORCID: https://orcid.org/0000-0001-9412-5805

\section{Popadych Olena}

Candidate of Pedagogical Sciences, Assistant Professor, Department of General and Higher Education Pedagogy, Faculty of Social Sciences. Uzhhorod National University. Uzhhorod, Ukraine.

E-mail: noshmeedb@gmail.com

ORCID: https://orcid.org/0000-0003-1426-4114

\section{Bondarenko Yuliia}

Doctor of Pedagogical Sciences, Professor, Department of Special and Inclusive Education, Institute of Pedagogy and Psychology. Sumy State Pedagogical University. Sumy, Ukraine.

E-mail: uliapakul@gmail.com

ORCID: https://orcid.org/0000-0002-6190-7648 